\title{
Failure of malaria chemoprophylaxis with mefloquine in an oversize traveller to Mozambique
}

\author{
Federico Gobbi ${ }^{1 *}$, Andrea Rossanese ${ }^{1}$, Dora Buonfrate ${ }^{1}$, Andrea Angheben ${ }^{1}$, Gianluigi Lunardi ${ }^{2}$ and Zeno Bisoffi ${ }^{1}$
}

\begin{abstract}
A case of failure of mefloquine prophylaxis in an oversize traveller, who correctly took the drug. This case seems to be attributed to mefloquine resistance, however it is suggested that mefloquine dosage should be modulated by body weight, as is already indicated by some authorities.
\end{abstract}

Keywords: Failure, Mefloquine, Chemoprophylaxis, Malaria

\section{Background}

The correct dosage for mefloquine in anti-malarial chemoprophylaxis is $5 \mathrm{mg} / \mathrm{kg}$ [1]. The vast majority of international $[2,3]$ and national [4] guidelines on malaria prevention suggests a prophylactic dose of $250 \mathrm{mg}$ per week in adult travellers. However, regardless the product label, some national Travel Medicine Societies, such as the Swiss and the Austrian ones, suggest to modulate the drug dosage by body weight (Table 1) [5,6]: $1 \frac{1 / 2}{2}$ tablet per week for patients weighing $>90 \mathrm{~kg}$, two tablets per week for the patients weighing $>120 \mathrm{~kg}$. The dosage issue concerns not only the overweight, but also the low weight travellers. Those weighing $<60 \mathrm{~kg}$ may poorly tolerate a whole tablet of mefloquine per week [7-9].

A case is presented of mefloquine failure in an oversize traveller, that was initially attributed to insufficient dosage.

\section{Case presentation}

A 50-year-old Italian patient was admitted to the Centre for Tropical Diseases (CTD) with fever $\left(39^{\circ} \mathrm{C}\right)$ and diarrhoea since three days. He reported having visited many Catholic missions over several years (he is a priest) in subSaharan Africa, Asia and Latin America. The average length of stay was between 10 and 14 days. He had been vaccinated against yellow fever, hepatitis $A$ and $B$, and typhoid fever. From $20^{\text {th }}$ to $31^{\text {st }}$ March 2012, he had travelled to Mozambique, regularly taking malaria chemoprophylaxis with mefloquine, one tablet $(250 \mathrm{mg})$ weekly, starting

\footnotetext{
* Correspondence: federico.gobbi@sacrocuore.it

${ }^{1}$ Centre for Tropical Diseases, Sacro Cuore-Don Calabria Hospital, Verona, Negrar, Italy

Full list of author information is available at the end of the article
}

one week before travelling and continuing for four weeks after return: he took the last tablet on $24^{\text {th }}$ April. He presented to CTD on May $18^{\text {th }} 2012$. His weight was $144 \mathrm{~kg}$. He had no history of alcohol, tobacco or illicit drugs abuse. He was not under any long-term medication. The hearth rate was 90 beats per minute and the blood pressure 140/ $70 \mathrm{~mm}$ Hg. Physical examination was unremarkable, except for a distended abdomen. Quantitative buffy coat (QBC), antigen malarial test and blood smears resulted positive for Plasmodium falciparum malaria, with a parasitaemia of $0.13 \%(6330 / \mu \mathrm{l})$. The blood tests showed $7430 \mathrm{WBC} / \mu \mathrm{l}$, $\mathrm{C}$ reactive protein $142 \mathrm{mg} / \mathrm{L}$. The patient was treated with artemether (tablet $50 \mathrm{mg}$ ), eight tablets the first day, then three tablets/day until the fifth day, followed by four tablets of sulphamethoxypyrazine/pyrimethamine $500 \mathrm{mg} / 25 \mathrm{mg}$ (artemisinin-based combination artemisinin-based combination therapies were not yet available). After two days of treatment, blood films resulted negative and remained so at follow-up, one month later.

Whole blood and plasma mefloquine concentrations were retrospectively evaluated on cryo- preserved $\left(-80^{\circ} \mathrm{C}\right)$ samples taken on admission ( 25 days after the last mefloquine intake), by high pressure liquid chromatography (HPLC) coupled with ultraviolet diode-array detection $[10,11]$.

Whole blood and plasma mefloquine concentrations were 516 and $320 \mathrm{ng} / \mathrm{mL}$, respectively.

\section{Discussion}

Despite a correct anti-malarial chemoprophylaxis, the patient developed $P$. falciparum malaria. Therefore, it was concluded that either the strain of $P$. falciparum was 
Table 1 Dosage of mefloquine tablet $(250 \mathrm{mg})$ in Swiss/Austrian malaria prophylaxis recommendations

\begin{tabular}{lc}
\hline $\mathbf{1 2 0} \mathbf{~ k g}$ & $\mathbf{2}$ tablets (twice weekly on tablet: e.g. Mon \& Thu) \\
\hline$>90 \mathrm{~kg}$ & 1 and $1 / 2$ tablets (twice weekly on tablet: e.g. Mon \& Thu) \\
$>60 \mathrm{~kg}$ & 1 tablet \\
$40-60 \mathrm{~kg}$ & $3 / 4$ tablet \\
$20-40 \mathrm{~kg}$ & $1 / 2$ tablet \\
$10-20 \mathrm{~kg}$ & $1 / 4$ tablet \\
$<10 \mathrm{~kg}$ & $5 \mathrm{mg} / \mathrm{kg}$ \\
\hline
\end{tabular}

resistant to mefloquine, or its dose was insufficient according to the patient's body weight. At first, the failure was attributed to an insufficient dosage according to the patient's weight $(144 \mathrm{~kg})$, but later mefloquine concentration was assessed on pre-treatment plasma and blood samples that had been stored.

The mefloquine level in the patient's bloodstream at admission was within the expected range, considering the breakthrough mefloquine levels $>620 \mathrm{ng} / \mathrm{ml}$ and a half-life of 21 days (Product information Lariam ${ }^{\circ}$, Roche, the Netherlands). Considering these data, $P$. falciparum resistance to mefloquine was more probable, despite the limitation of a single point in time determination.

A review of literature was performed to collect the characteristics and probable causes of reported cases of failure of mefloquine prophylaxis. PubMed was searched using the following keywords: mefloquine, chemoprophylaxis, failure, Africa. Thirteen papers were retrieved [12-24], describing a total of 31 cases (Table 2).
Only three cases were reported in the last 15 years, while the others were reported between 1990 and 1998 . In most of the cases $(25 / 31)$ the infection had been acquired in West Africa, in six cases in East Africa (one each in Malawi, Tanzania, Madagascar, Mozambique, and two in Somalia). Six patients were females and 25 males; six were children and 25 were adults between 18 and 50 years of age. Three patients developed P. falciparum malaria while in the endemic country, 28 patients after return. In the latter group, 16 travellers became ill within four weeks after return (still under prophylaxis) and 12 developed the disease after the last dose of mefloquine. The median onset of symptoms after return was 28 days (range 3-91 days). In all cases resistance to mefloquine was presumed, although for some of them drug concentration in plasma was not available.

In relation to the first suspicion, there is no agreement on the need to adjust mefloquine regimen to body weight. It is worth considering this factor, though, also taking into account the lipophilic behaviour of this drug, which has an apparent volume of distribution between 13 to $401 \mathrm{~kg}^{-1}$ with a mean of $201 \mathrm{~kg}^{-1}$. Both apparent volume of distribution and individual systemic clearance are probably influenced by body fat, thus causing different pharmacokinetic profiles $[7,25,26]$.

In conclusion, although in this case the failure of mefloquine prophylaxis was most probably due to drug resistance, the indication given by some scientific societies that mefloquine dosage should be modulated by body weight seems reasonable and should probably be considered in new guidelines.

Table 2 Papers describing mefloquine prophylaxis failure in travellers to Africa

\begin{tabular}{|c|c|c|c|c|c|}
\hline Author & Age & Sex & Country of infection & $\begin{array}{l}\text { Symptoms onset } \\
\text { (before return) }\end{array}$ & $\begin{array}{l}\text { Symptoms onset } \\
\text { (days after return) }\end{array}$ \\
\hline Callen (2006) & 25 & M & Gambia & - & 4 \\
\hline Wichmann (2003) & 44 & $\mathrm{~F}$ & Tanzania & - & 23 \\
\hline Gary-Toussaint (2002) & 45 & M & Senegal & - & 41 \\
\hline Gizolme (1998) & $40,12,9$ & $F, M, F$ & Togo & - & $63,77,91$ \\
\hline Lobel (1998) & $31,22,30,26,25$ & $M, M, M, F, M$ & Niger, Sierra Leone, Cameroon, RCA & Y & - \\
\hline Matteelli (1995) & 20 & M & Mozambique & - & 3 \\
\hline \multirow[t]{2}{*}{ Magill (1993) } & 23 & M & Somalia & Y & - \\
\hline & 21 & M & Somalia & Y & - \\
\hline Raccurt (1991) & $3,30,28,22,40,44,23,23,27$ & $\begin{array}{c}F, M, M, M, M \\
M, M, M, M\end{array}$ & $\begin{array}{l}\text { Senegal, Burkina Faso, Niger, } \\
\text { Nigeria, Mali, Ivory Coast, Togo }\end{array}$ & - & $3,4,6,13,15,19,21,25,26$ \\
\hline Ringwald (1990) & $5,28,34,37$ & $M, M, M, M$ & Burkina Faso, RCA, Madagascar, Togo & - & $19,26,31,32$ \\
\hline Ooi (1991) & 26 & M & Malawi, Kenya & - & 21 \\
\hline Durieux (1990) & 18 & M & Burkina Faso & - & 58 \\
\hline Gay (1990) & 6 & M & Senegal, Ivory coast & - & 55 \\
\hline Bricaire (1990) & $6,34,40,45,50$ & $M, M, M, M, F$ & Mali, Sierra Leone, Senegal, RCA & - & $7,30,45,46,61$ \\
\hline
\end{tabular}




\section{Consent}

Written informed consent was obtained from the patient for the publication of this report.

\section{Competing interests}

The authors declare that they have no competing interests.

\section{Authors' contribution}

$F G, A R$ visited and followed-up the patient. AA and DB performed Pubmed search. FG and DB have been involved in drafting the manuscript. GL detected drug concentration. ZB and AA revised the manuscript critically for important intellectual content. All the authors have given final approval of the version to be published.

\section{Author details}

${ }^{1}$ Centre for Tropical Diseases, Sacro Cuore-Don Calabria Hospital, Verona, Negrar, Italy. ${ }^{2}$ Oncology Department, Sacro Cuore-Don Calabria Hospital, Verona, Negrar, Italy.

Received: 23 July 2013 Accepted: 16 December 2013

Published: 18 December 2013

\section{References}

1. Schlagenhauf P, Adamcova M, Regep L, Schaerer MT, Bansod S, Rhein HG: Use of mefloquine in children - a review of dosage, pharmacokinetics and tolerability data. MalarJ 2011, 10:292.

2. CDC: Health Information for International Travel 2012. The yellow book. www.cdc.gov/yellowbook.

3. WHO: International travel and health. Geneva: World Health Organization; 2012. www.who.int/ith

4. Lalloo DG, Shingadia D, Pasvol G, Chiodini PL, Whitty CJ, Beeching NJ, Hill DR, Warrell DA, Bannister BA: UK malaria treatment guidelines. J Infection 2007, 54:111-121.

5. DTG: Empfehlungen zur Malaravorbeugung; 2011. www.dtg.org

6. Hatz C, Nothdurft H: Malaria protection for short-term travelers. Internist 2006, 47(8):810-812. 814-817.

7. van Riemsdijk MM, Sturkenboom MC, Ditters JM, Tulen JH, Ligthelm RJ, Overbosch D, Stricker BH: Low body mass index is associated with an increased risk of neuropsychiatric adverse events and concentration impairment in women on mefloquine. Br J Clin Pharmacol 2004, 57:506-512.

8. Schlagenhauf $P$, Tschopp A, Johnson R, Nothdurft HD, Beck B, Schwartz E, Herold M, Krebs B, Veit O, Allwinn R, Steffen R: Tolerability of malaria chemoprophylaxis in non-immune travellers to sub-Saharan Africa: multicentre, randomised, double blind, four arm study. BMJ 2003, 327:1078.

9. Ollivier $L$, Tifratene $K$, Josse $R$, Keundjian A, Boutin JP: The relationship between body weight and tolerance to mefloquine prophylaxis in non-immune adults: results of a questionnaire-based study. Ann Trop Med Parasitol 2004, 98:639-641.

10. Green MD, Bergqvist Y, Mount DL, Corbett S, D'Souza MJ: Improved validated assay for the determination of mefloquine and its carboxy metabolite in plasma, serum and whole blood using solid-phase extraction and high-performance liquid chromatography. J Chromatogr $B$ Biomed Sci Appl 1999, 727:159-165.

11. Gutman J, Green M, Durand S, Rojas OV, Ganguly B, Quezada WM, Utz GC, Slutsker L, Ruebush TK 2nd, Bacon DJ: Mefloquine pharmacokinetics and mefloquine-artesunate effectiveness in Peruvian patients with uncomplicated Plasmodium falciparum malaria. Malar J 2009, 8:58.

12. Callen EC, Church CO: Plasmodium falciparum malaria associated with mefloquine failure in Gambia. Pharmacotherapy 2006, 26:1526-1528.

13. Wichmann O, Betschart B, Loscher T, Nothdurft HD, Sonnenburg FV, Jelinek T: Prophylaxis failure due to probable mefloquine resistant $P$. falciparum from Tanzania. Acta Trop 2003, 86:63-65.

14. Gari-Toussaint M, Pradines B, Mondain V, Keundjian A, Dellamonica P Le Fichoux Y: [Senegal and malaria. True prophylactic failure of mefloquine] (in French). Presse Med 2002, 31:1136.

15. Gizolme D, Receveur MC, Bouzidi P, Theron P: [Relative failure of mefloquine chemoprophylaxis on the occasion of a trip to Togo. 3 cases within the same family] (in French). Presse Med 1998, 27:1575-1576.
16. Lobel HO, Varma JK, Miani M, Green M, Todd GD, Grady K, Barber AM: Monitoring for mefloquine-resistant Plasmodium falciparum in Africa: implications for travelers' health. Am J Trop Med Hyg 1998, 59:129-132.

17. Matteelli A, Chiodera A, Castelli F, Caligaris S, Minardi C, Carosi G: Failure of mefloquine chemoprophylaxis for malaria in Mozambique. J Travel Med 1995, 2:260-261

18. Magill AJ, Smoak BL: Failure of mefloquine chemoprophylaxis for malaria in Somalia. N Engl J Med 1993, 329:1206.

19. Raccurt CP, Dumestre-Toulet $V$, Abraham E, Le Bras M, Brachet-Liermain A, Ripert C: Failure of falciparum malaria prophylaxis by mefloquine in travelers from West Africa. Am J Trop Med Hyg 1991, 45:319-324.

20. Ooi WW: Failure of mefloquine prophylaxis in east Africa. N Engl J Med 1991, 324(2):130.

21. Durieux I, Boibieux A, Biron F, Ringwald P, Piens MA, Peyramond D: [Failure of chemoprevention with mefloquine in western Africa] (in French). Presse Med 1990, 19(33):1548-1549.

22. Ringwald P, Bartczak S, Le Bras J, Bricaire F, Matheron S, Bauchet J, Coulaud JP: Failure of anti-malarial prophylaxis with mefloquine in Africa. Trans $R$ Soc Trop Med Hyg 1990, 84:348-349.

23. Gay F, Binet MH, Bustos MD, Rouveix B, Danis M, Roy C, Gentilini M: Mefloquine failure in child contracting falciparum malaria in West Africa. Lancet 1990, 335:120-121.

24. Bricaire F, Gay F, Caumes E, Datry A, Bustos D, Felix H, Paris L, Danis M, Gentilini M: [Failure of prevention of malaria by mefloquine in West Africa] (in French). Ann Med Onterne 1990, 141(6):512-514.

25. Karbwang J, White NJ: Clinical pharmacokinetics of mefloquine. Clin Pharmacokinet 1990, 19:264-279.

26. Palmer KJ, Holliday SM, Brogden RN: Mefloquine: a review of its antimalarial activity, pharmacokinetic properties and therapeutic efficacy. Drugs 1993, 45:430-475.

doi:10.1186/1475-2875-12-451

Cite this article as: Gobbi et al:: Failure of malaria chemoprophylaxis with mefloquine in an oversize traveller to Mozambique. Malaria Journal 2013 12:451.

\section{Submit your next manuscript to BioMed Central and take full advantage of:}

- Convenient online submission

- Thorough peer review

- No space constraints or color figure charges

- Immediate publication on acceptance

- Inclusion in PubMed, CAS, Scopus and Google Scholar

- Research which is freely available for redistribution

Submit your manuscript at www.biomedcentral.com/submit
C Biomed Central 